\title{
Coercion Behind the Implementation of Accrual-based Accounting System in the Government Financial Statements
}

\author{
Bestari Dwi Handayani ${ }^{1}$ Ismiyati $^{2}$, Hengky Pramusinto ${ }^{3}$ \\ \{bestarihandayani@mail.unnes.ac.id $\left.{ }^{1}\right\}$ \\ Universitas Negeri Semarang, Indonesia ${ }^{1,2,3}$
}

\begin{abstract}
This study aims to socially construct the phenomenon of the accrual-based accounting systems implementation on Government Financial Statements from the perspectives of preparers Government Financial Statements. Then, the specific objectives of this study are to deeply understand 1) the responses of the preparers on the accrual-based accounting systems implementation in Government Financial Statements; 2) the meaning behind the responses of prepares on such implementation in the context of the Central Government of Indonesian. This qualitative research was carried out within interpretive paradigm and used phenomenological methods. Data were collected by conducting interviews, observation and documentation. Then, data were analyzed by adopting the analytical method developed by Sanders (1982) with several modifications. The study found that preparers have loyalty response. The study also found that the implementation of accrual-based accounting system does not only have meanings from the technical aspects but also coverts a coercion process.
\end{abstract}

Keywords: Loyalty, Coercion, Accrual-based Accounting System, Government Financial Statements

\section{Introduction}

The government of the Republic of Indonesia has been adopting an accrual-based accounting system as part of political and economic reform post-financial and -political crises of 1998 [1]. In order to overcome the crises, the government provided legal instruments on which the reform based on.

Similarly, public accounting practice has experienced a significant reform since 1998, in which government performance in doing its public service has become the major theme. Public financial statement preparation has shifted its purpose towards responsibility and accountability reporting of each interested party as well as government performance [2]. The essence of accountability reflects a responsible relation between two different players, i.e., accountor and accountee. The accountor is responsible for financial management activities and their consequences to the accountee [3].

The government institution accountability is more broadly manifested in its responsibility for the financial management and to the citizens who own the money. In a narrower definition, accountability means a responsible manner from agent to superior. Managers at the lowest tier are responsible to the middle-tier manager and those in the middle-tier are in turn responsible for the top-tier managers. Accounting records and financial statement are prepared in detail 
according to the degree of responsibility. As this mechanism holds, the construction of the accounting system becomes much more important than the numbers and digits presented within the financial statement [4].

Performance is one of aspect to measure how successful the government in governing, how capable it discovers and manages financial sources to fulfill the necessities to support the public service activities. A good performance means successful governing endeavors [5].

Dramatical changes in public sector management from traditional system guided by rigid and hierarchical spirit to market-flexible and -accommodating system is an integral part of the role of the state to perform analyses and to prepare regulations on how the accrual-based accounting system should be properly implemented according as the citizens expect towards the government accountability and performance [6].

Public financial management in Indonesia has been stipulated on legal instruments, such as Law 17/2003 on Public Finance, Law 1/2004 on Public Treasury, and Law 15/2004 on Surveillance on Public Financial Management and Responsibility. Furthermore, Law 17/2003, in article 36 (1), requires that acknowledgement and measurement of income and spending applies an accrual-based accounting system, which is performed in a five-year term since the Law 17/2003 has taken effect. Under such requirement, the accrual-based accounting system internalization is distributed to all public institutions nationwide, including those at the local level of governments. The Law 17/2003 also considers the Public Accounting Standard (Standar Akuntansi Pemerintahan, $S A P$ ) as a mandatory requirement as the basis on which the accrualbased accounting sistem to be implemented at the public institutions under the SAP (stipulated in the Government Act 24/2005, which, in turn, has been amended by the Government Act $71 / 2010)$.

The Government Act 71/2010 clearly legitimates the phase of the public management in Indonesia using the accrual-based accounting system at both central and local governments. Its promulgation gives a consequence to all government institutions to prepare their Financial Statements according to the accrual-based accounting system. The Public Financial Statement is an important part of the effort towards accountability, efficiency, and effectiveness of the government performance.

This study had an objective to capture a phenomenon of the accrual-based accounting system implementation in the Public Financial Statement preparation through the response of the Public Financial Statement preparers. The study applied a phenomenological method to find out the essence of meaning of a response [7][8][9][10]. The essence of response meaning discovered in the Financial Statement in this study dealt with a coercion of the Public Financial Statement prepares as the ones in charge of and responsible for the Financial Statement preparation.

\section{Research Questions}

This study proposes the following research questions:

a) How was the response of the Public Financial Statement preparers to the accrual-based accounting system implementation in the Public Financial Statement preparation?

b) How was the meaning behind the response of the Public Financial Statement preparers to the accrual-based accounting system implementation in the Public Financial Statement preparation? 


\section{Method}

This study was a qualitative research with an interpretive paradigm using a phenomenological method. The method explains an expression of the meaning behind the phenomenon by digging into the depth of actor's consciousness to obtain the essence of the phenomenon to be exposed [11][12]. Phenomenology explains subjective 'lived experience' instead of generalization, in which the most important aspect is how the 'ived experience' speaks up free of intervention and methodological simplification, which tends to deviate the experience naturalization.

The above definition led this study to the way of understanding response and meaning behind the phenomenon of the particular actor concerning the accrual-based accounting system implementation at the public sector (i.e., the preparers of the Public Financial Statement). In doing so, the study needed a method far beyond informant's consciousness and investigation of direct experience to gain the meaning of the phenomenon in question. It was the prime reason for this study to apply the phenomenological method.

Sanders [7] presents the stages of research using phenomenological method as follows: 1) data description, in which informant interviews are transcribed into narrative; 2) phenomenology reduction, where statements within the interviews are interpreted; 4) noetic/noematic correlate, in which research meaning is synthesize; and 4) eidetic reduction, where the study discovers the essence of the research meaning.

This study limited its unit of analysis to the central government to bring the research more focused on the implementation of the national government of Indonesia in implementing the accrual-based accounting system during the preparation of the Public Financial Statement. The study attempted to discover holistic meaning in the public context of the national level.

Research object of this study were the responses of the Public Financial Statement preparers. Retrieval of informants compiling the Government Financial Statements because they are the parties directly related to policies regarding the obligations of government agencies to implement an accrual-based accounting system in preparing their financial statements. The preparers consisted of those who worked at the Ministry of Finance (Department of Treasury) as the preparers of technical guidance and Central Public Financial Statement Consolidation (LKPP), the Ministry of Education and Culture, the Ministry of Health, and the Ministry of Public Works as the contributors for the LKPP prepared by the Ministry of Finance. Table 1 enlists the research informants.

Table 1. List of Research Informants

\begin{tabular}{|c|c|c|}
\hline No & Name (Aliases/Pseudonyms)* & Institution \\
\hline 1 & Ersa & Ministry of Finance \\
\hline 2 & Hafidudin & Ministry of Finance \\
\hline 3 & Maya & Ministry of Finance \\
\hline 4 & Agus & Ministry of Finance \\
\hline 5 & Adi & Ministry of Public Works \\
\hline 6 & Asih & Ministry of Public Works \\
\hline 7 & Rahmat & Ministry of Education and Culture \\
\hline 8 & Yanti & Ministry of Health \\
\hline
\end{tabular}

*Names were in aliases or pseudonyms for the informants' confidentiality. 
The informants were selected under the terms that they were relevant to the Public Financial Statement and they agreed to provide complete and accurate information. The selection used a technique namely snowball sampling, in which the informants were decided without determining the exact numbers by discovering information relevant to the research questions. The informants search ended after the need for research information had been considered adequate.

Research data were collected by way of in-depth interview with the informants to grab the research phenomenon through a phenomenological analysis and of outreached participant observation on the research phenomenon. Document collections then supported the data collection activities.

\section{Results and Discussion}

This study had undergone stages of analysis of the phenomenological research to find out the results. The first stage was performing data description of the interviews with the informants. It was then followed by phenomenology reduction stage, in which the study performed interpretation of the statements in the interviews, resulting in 43 different meanings. These 43 meanings were then divided into 15 major categories.

The third stage was noetic/noematic correlate analysis, which resulted in three meaning syntheses. These three meaning syntheses were important branches for constructing understanding of the meaning of the accrual-based accounting system implementation in the Public Financial Statement. The eidetic reduction analysis stage then followed to find out the essence of the research meaning. According to the integration of the three data sources, i.e., interviews, observation, and document recording, the study obtain the findings as follows:

Answering research questions regarding the response of compilers of Government Financial Statements, this study uses response levels according to Blake et al. [13] which categorizes responses ranging from the loudest to the softest. The first states disagreement or reject and exit from the organization. Both actively and constructively provide aspirations to improve conditions (voice). Third, build loyalty, namely passively but still optimistic waiting for the improvement of conditions (loyalty). The fourth is passively letting things get worse (neglect).

Based on the results of interviews with research informants, the response that can be captured from the compilers of the Government Financial Statements to the implementation of an accrual-based accounting system in the preparation of Government Financial Reports is "loyalty", namely the compilers of Government Financial Statements build loyalty passively but remain optimistic waiting for the improvement of conditions. This can be seen from their understanding of the regulations that require the implementation of an accrual-based accounting system. Research informants stated that they carried out all regulations regarding the obligation to use an accrual-based accounting system in preparing pragmatic Government Financial Statements as a form of responsibility and work professionalism.

Government financial report compilers also believe that many obstacles that still arise in implementing accrual-based accounting systems will slowly be resolved and resolved. They believe that the constraints that arise solely because of the accrual-based accounting system are new things that are still foreign to them. However, over time, and with various efforts made by the government to make this accrual-based accounting system easy to understand and all obstacles will pass. 
Meanwhile, to answer research questions regarding the meaning of the responses of compilers of government financial statements to the implementation of the accrual-based accounting system, this study found the results interviews proved that the informants did not voluntarily implement the regulations and the laws issued by the government, in particular SAP 2010. Mr. Adi, a financial statement preparer at the Ministry of Public Works, reported as follow:

"Ya mau gimana lagi mbak, mau setuju atau tidak setuju, kita tetap harus melaksanakannya, karena ini kan sudah diatur dalam Undang-Undang dan Peraturan Pemerintah". [Like or dislike, we had to obey and to implement it as the Law and the Government Regulation require].

Similarly, Mr. Agus from the Ministry of Finance added the following statement:

"Namun mau bagaimana lagi, ini kan sudah diatur pemerintah dengan UndangUndang”. [The Law says so.... What can we do?].

Both informants stated that they did not have any choice but obeying the mandatory requirements for the accrual-based financial system in the Financial Statement preparation. It was proven that they did not do it voluntarily.

This non-voluntary response tended to indicate that the state was a repressive political group, which enforced the accrual-based accounting system in the financial statement preparation. This phenomenon was likely to distract civil society discourse towards state power discourse. The civil society movement was powerless to make a bargaining with the government in the SAP 2010 implementation. The informants implied a hopelessness to accept the government policy on the accrual-based accounting system without question.

The non-voluntary stance towards the accrual-based accounting system implementation led to pragmatic attitude. As employees, the informants only do what the superiors asked them to do strictly based on the laws and regulations.

The informants believed that once the accrual-based accounting system implementation in the Public Financial Statement had been in effect, the requirement did not apply as it had to be. They supposed that the Law had been constructed in such way that nothing they could ever do to despise it. Mr. Hafidudin, the financial staff at the Ministry of Finance, reported as follow:

"Kita lebih profesional saja mbak dalam melaksanakan tugas, ini adalah bagian dari tanggung jawab dan tugas kita dalam bekerja menyusun Laporan Keuangan Pemerintah". [We are required to be more professional. This is part of our duty as the preparers of the Public Financial Statement].

Similarly, Mr. Adi from the Ministry of Public Works stated the following:

"Kita harus melaksanakan tugas dan tanggungjawab ini dengan sebaik-baiknya". [He had to finish the duty and do our responsibility at our best].

Mr. Rahmat from the Ministry of Education and Culture added the following statement:

"Sekarang kita tinggal melaksanakannya dengan baik, tugas kita sebagai karyawan yang bertanggung jawab menyusun laporan keuangan kementerian pendidikan dan 
kebudayaan, ya itu saja dilakukan dengan sebaik-baiknya". [We are the employees at the Ministry of Education and Culture who are in charge of preparing the public financial statement. We must do that].

Citations from the informants, i.e., the preparers of the Public Financial Statement, indicated that they prepared the Financial Statement according to the accrual-based accounting system merely for fulfilling the responsibility as good employees. They did the job as much as they could take it amid obstacles and problems that continued to grow as the preparation process went on. The informants as the preparers did the best, they could to show their professionalism as the superiors and the central government required during the preparation of financial statement using the accrual-based accounting system.

To the informants, problems had to arise during the implementation because it was a new system, therefore, more knowledge had to be learned. However, the informants were confident that someday the problems would be much easier to solve. The accrual-based accounting system, to the informants' awareness, would become a perfect system for the Public Financial Statement.

Such pragmatic attitude led the informants to implement the accrual-based accounting system as a ritual method of financial recording. The public financial reporting practice had to be understood as an effort of recording and reporting the economic reality according to the reallife situation. In practice, it turned out to be the perfect way to fulfill the responsibility and to obey the regulations. Mr. Agus from the Ministry of Finance explained about this:

"Yaa...ini sudah menjadi amanat Undang-Undang, kita memiliki kewajiban untuk menjalankannya, kita memegang prinsip profesional kerja saja mbak". [As the Law requires. We are responsible for it. We must hold professionalism at work].

Mr. Adi from the Ministry of Public Works agreed with Mr. Agus and Ms. Ersa by commenting as follow:

"Ya mau gimana lagi mbak, mau setuju atau tidak setuju, kita tetap harus melaksanakannya, karena ini kan sudah diatur dalam Undang-Undang dan Peraturan Pemerintah. Kita harus melaksanakan tugas dan tanggungjawab ini dengan sebaik-baiknya". [We have no choice. The Law and the Government Act ask us to do so. It is our responsibility].

These citations express the fact, which indicated that the obedience towards formal regulation on the financial statement preparation under the Government Act and Law in practice had been reduced into a ritual. The public accounting standard, which should had been a guidance for preparing and presenting the financial information in the form of the Public Financial Statement, could only become a bunch of "mantra", which had to follow for the sake of stakeholders. Accordingly, the presentation of the Public Financial Statement was driven into a meaningless calculative-mathematical way-of-thinking.

Amid such deteriorating situation the government continued its effort to internalize the accrual-based accounting system in the Public Financial Statement preparation in order to implement the good accrual-based accounting system. The internalization process is useful for understanding the employees (the preparers) about the accrual-based accounting system. This effort had been made through socialization, training, and workshop. Ms. Ersa from the Ministry of Finance explained as follow: 
"Upaya yang sudah dilakukan banyak sekali mbak, dari yang tadi saya sampaikan, untuk mengatasi persoalan sumber daya manusia, kita sudah melakukan berbagai macam sosialisasi, workshop, bintek dan juga inhouse training, semua itu sudah kita lakukan”. [Plenty of efforts have been done. Socialization, technical guidance, in-house training. We did all].

Mr. Rahmat from the Ministry of Education and Culture agreed that they attended the socialization and workshop on the accrual-based accounting system:

\begin{abstract}
"Informasi mengenai sistem akuntansi berbasis akrual saya peroleh dari sosialisasi dan pelatihan-pelatihan yang dilakukan di lingkungan kementerian pendidikan dan kebudayaan ini mbak". [Socialization and training help me get further information about accrual-based accounting system for this institution, Ministry of Education and Culture].
\end{abstract}

The above citations indicated that the government had performed internationalization process of the accrual-based accounting system to enrich the knowledge of the relevant employees about the truth and objectivity of the system (Berger and Luckman, 2013). The internalization process took place when the social reality had experienced objectification, dragging it back to the consciousness during the socialization. At this stage, the internalization had a function of transmitting the accrual-based system as an independent reality for the employees who just knew about it. Therefore, the accrual-based accounting system continued to exist over time.

The interviews with the preparers of the Public Financial Statement indicated that the government actually had prepared anything from regulations and standards, from system to information technology, and from socialization to workshop and training. All were done for the sake of better and more competent accrual-based accounting system over time.

Despite all efforts that had been done, the real-life implementation was overshadowed by problems so the delay had to be done. The accrual-based accounting system in the Public Financial Statement, however, implied poorly planned change in the public accounting system.

The poorly planned mechanism in the accounting system and the public financial statement was elaborated by the informants, in which he presented three major problems, i.e., inconsistent regulation, inadequate information system, and inadequate human resource. Mr. Adi from the Ministry of Public Works explained:

"Iya, memang berkaitan dengan kesiapan segala hal mengenai implementasi sistem akuntansi berbasis akrual memang masih sangat perlu dipersiapkan mbak, aturannya berubah-ubah, ganti berkali-kali, sosialisasi dilakukan berkali-kali kalau sistemnya juga diganti-ganti terus, itu bikin kita bingung malahan mbak". [It is still inconsistent. It changes over time so we get confused of what should be or should not be done].

In addition, Ms. Asih from the Ministry of Public Works added the following:

"Ini kalau dari sisi kementerian PU, sebenarnya untuk sarana penunjangnya memang masih perlu ditingkatkan lagi, walaupun sebenarnya ada sistem aplikasi penunjangnya mbak, tetapi sistem ini kadang juga masih bermasalah, sehingga kadang kita mengalami keterlambatan dalam menyampaikan laporan keuangan 
kementerian PU ke kementerian keuangan". [We need more facilities to implement the system. We still have problems but I think our office has been doing something to make it better].

Mr. Hafidudin from the Ministry of Finance also gave his statement about the problems surrounding the accrual-based accounting system as follow:

"Dalam hal sumber daya manusia, pemerintah juga seperti tadi yang sudah saya sampaikan mbak, masih belum merata secara kualitas dan kompetensinya". [Human resource becomes the priority for the government. It has not been distributed equally though].

The above statements indicated that the accrual-based accounting system in Indonesia remained problematic. The government still had a lot of things to do it right in order to prepare the good Public Financial Statement by the accrual-based accounting system.

Based on the findings regarding the compulsion of the compilers of the Government Financial Statements to the implementation that was not planned so that there were various obstacles, in fact accounting practice is a social interaction within a country in response transaction and people need for accounting information [14][15]. Therefore, accounting practice is an integral part of national interest to enforce regulations to create harmony and legal stand for the people in performing the practice.

State is an institution with the most adequate understanding of the will of individuals within society. It has authority to organize structural order for the citizens in economic, social, and political lives. In terms of accrual-based accounting system implementation in the Public Financial Statement preparation, the state has an interest to prepare regulations and standards which all public institutions rely on during the Financial Statement preparation.

To create a mandatory requirement to all public institutions in the implementation of the accrual-based accounting system in the Financial Statement, the national government needs to formulate Laws and other government acts. Indonesia has stipulated Law 17/2003 on Public Finance. This Law is the milestone of the proposed financial management system regulations.

Once the Law 17/2003 had been stipulated, the government then took the follow-up action by issuing some other Laws and Acts, as far as Government Act 71/2010 on SAP, which contains mandatory requirements for all public institutions to cope with as late as 2015. In support of all of these legal products, the government had also taken strategic measures and implementation, such as by providing workshops, as well as training and education, for public institutions, ministries, in particular at the central level of government. Efforts had also been made to provide more sophisticated infrastructures and facilities.

Law 71/2010 applies as a regulatory standard for financial statement prepared by public institutions, reflecting a correlating characteristic between power of regulation and power of authority in terms of legislation of authority and regulation enforcement. It indicates the power possessed by the dominant class (the state) or the order for suppressing other classes to obey the regulations. Based on this, it can be concluded that there is coercion carried out by the State behind the implementation of the accrual-based accounting system in the preparation of Government Financial Statements. Figure 1 describes the coercion behind the implementation of the accrual-based accounting system. 


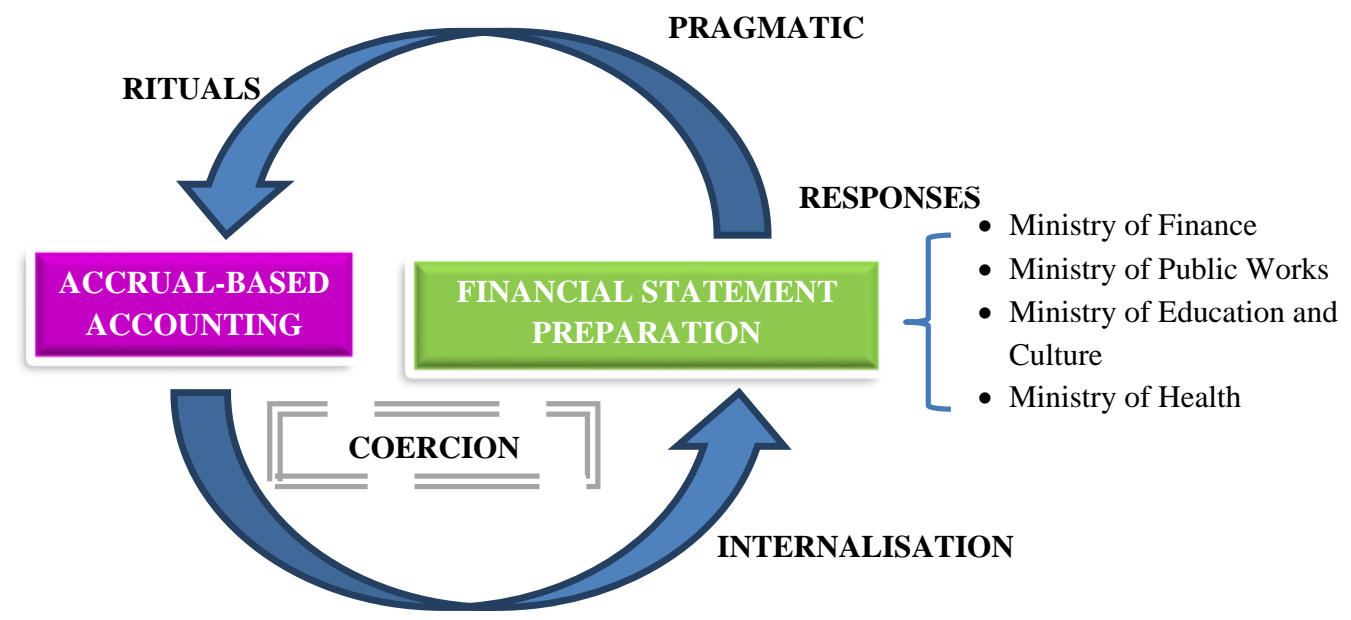

Fig. 1. Accrual-based Accounting and Coercion.

\section{Conclusion}

Accounting practice is a social interaction within a country in response transaction and people need for accounting information [14][15]. Therefore, accounting practice is an integral part of national interest to enforce regulations to create harmony and legal stand for the people in performing the practice.

Accounting practice in Indonesia has been stipulated within the Government Act 71/2010, which requires all public institutions to implement the accrual-based accounting system. This Act was in practice involuntarily accepted and implemented by any relevant employees and institutions. The response to the mandatory accrual-based accounting system in the Public Financial Statement was pragmatic in nature as the employees did it only to fulfill the responsibility and for the sake of obedience.

This study found the response from the compilers of the Government Financial Statements to the implementation of the accrual-based accounting system as a loyalty. The loyalty response shown by the compilers of this Government Financial Report can be seen from a pragmatic attitude only to carry out job duties and responsibilities in responding to regulations issued by the government.

This pragmatic attitude distracted the true meaning of the system implementation. The employees tended to give their understandings to the way of fulfilling the responsibility and doing their job. The obedience toward the standard requirements of the public accounting standards were no more than simply a ritual. No understanding and further knowledge whatsoever that the system was truly necessary to support the public financial statement. It was the economic reality that overshadowed the implementation of the accrual-based accounting system.

On the other hand, the government of Indonesia had made efforts to succeed the implementation of the accrual-based accounting system in the public financial statement by 
providing workshops, training and education, as well as socialization. However, changes in regulation, inadequacy in information system and human resource quality continued to give problems to the implementation of the system in the public spheres.

In the midst of various obstacles that occur in the process of implementing an accrual-based accounting system and the compulsion and pragmatic attitude of the compilers of Government Financial Statements, law 71/2010 applies as a regulatory standard for financial statement prepared by public institutions, reflecting a correlating characteristic between power of regulation and power of authority in terms of legislation of authority and regulation enforcement. It indicates the power possessed by the dominant class (the state) or the order for suppressing other classes to obey the regulations. Based on this, it can be concluded that there is coercion carried out by the State behind the implementation of the accrual-based accounting system in the preparation of Government Financial Statements.

\section{References}

[1] R. Harun and A. P. Sumarno, "Komunikasi politik sebagai suatu pengantar," Bandung Mandar Maju, 2006.

[2] D. Mardiasmo and A. MBA, "Akuntansi Sektor Publik," Yogyakarta Andi, 2009.

[3] A. Barton, "Professional accounting standards and the public sector-a mismatch," Abacus, vol. 41, no. 2, pp. 138-158, 2005.

[4] C. A. Bunea-Bontas and M. C. Petre, "Arguments for introducing accrual based accounting in the public sector,” Available SSRN 1491663, 2009.

[5] I. Syamsi, Pokok-pokok kebijaksanaan, perencanaan, pemrograman, dan penganggaran pembangunan tingkat nasional dan regional. Rajawali, 1986.

[6] P. Chand and M. White, "A critique of the influence of globalization and convergence of accounting standards in Fiji," Crit. Perspect. Account., vol. 18, no. 5, pp. 605-622, 2007.

[7] P. Sanders, "Phenomenology: A new way of viewing organizational research," Acad. Manag. Rev., vol. 7, no. 3, pp. 353-360, 1982.

[8] C. Moustakas, Phenomenological research methods. Sage publications, 1994.

[9] J. W. Creswell and C. N. Poth, Qualitative inquiry and research design: Choosing among five approaches. Sage publications, 2016.

[10] F. Collin, Social reality. Psychology Press, 1997.

[11] Roekhudin, "Ruwatan Sebagai Metode Pembebasan Sukerto Dampak Adopsi Basis FV Measurement," Account. Res. Train. Ser. 6-Posmodern Progr. Dr. Ilmu Akunt. JAFEB Univ. Brawijaya, 2013.

[12] S. Alex, "Filsafat Komunikasi," Bandung PT Remaja Rosdakarya, 2013.

[13] A. Davis-Blake, J. P. Broschak, and E. George, "Happy together? How using nonstandard workers affects exit, voice, and loyalty among standard employees," Acad. Manag. J., vol. 46, no. 4, pp. 475-485, 2003.

[14] R. T. Kiyosaki and S. L. Lechter, Rich Dad Poor Dad: What the Rich Teach Their Kids About Money-That the Poor and the Middle Class Do Not! Business Plus, 2001.

[15] C. Carter, S. Clegg, and M. Kornberger, "Re-framing strategy: power, politics and accounting," Accounting, Audit. Account. J., 2010. 